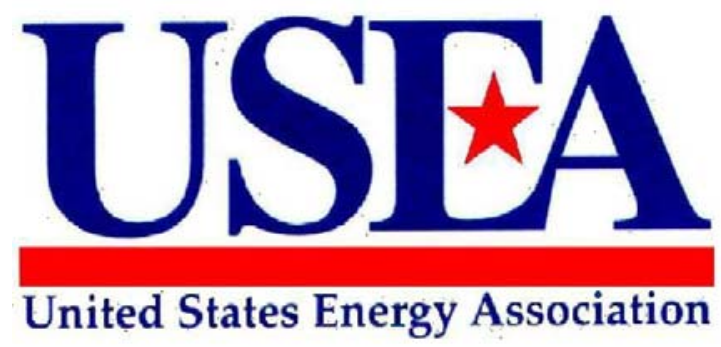

\title{
UNITED STATES ENERGY ASSOCIATION \\ INTERNATIONAL PARTNERSHIP FOR THE HYDROGEN ECONOMY MINISTERIAL CONFERENCE
}

Final Report

DOE Award Number: DE-FG36-03G013174

United States Energy Association Name of Project Director: William L. Polen 


\title{
UNITED STATES ENERGY ASSOCIATION
}

\section{INTERNATIONAL PARTNERSHIP FOR THE HYDROGEN ECONOMY MINISTERIAL CONFERENCE}

\author{
Final Report
}

\author{
DOE Award Number: DE-FG36-03G013174 \\ United States Energy Association \\ Name of Project Director: William L. Polen
}

\section{Executive Summary}

The inaugural ministerial meeting of the International Partnership for the Hydrogen Economy (IPHE) was conducted November 18-21, 2003 in Washington DC. On November 20, Secretary of Energy Spencer Abraham led ministerial representatives from the following fifteen nations and the European Commission in the signing of the IPHE Terms of Reference (TOR), thereby creating the IPHE as an institution designed to facilitate coordinated research on emerging hydrogen technologies: Australia, Brazil, Canada, China, France, Germany, Iceland, India, Italy, Japan, Norway, Republic of Korean, Russian Federation, United Kingdom, and the United States. The U.S. Departments of Energy, State and Transportation organized the ministerial meeting with the support of the United States Energy Association.

The IPHE is a major international component of the Administration's enhanced focus on hydrogen technology in addressing energy security and environmental needs over the coming century. The IPHE complements the $\$ 1.2$ billion five year hydrogen research and development commitment announced by President Bush in his 2003 State of the Union Address.

Energy needed to produce hydrogen can be obtained from many sources, including fossil fuels. When combined with carbon capture and storage or when produced from renewables or other emission free sources (i.e., nuclear), hydrogen production holds the promise of a plentiful fuel that will help safeguard the world's climate system. The cost of producing a unit of hydrogen, the cost of fuel cells and cost of developing hydrogen storage, transportation and distribution networks using current technology are impediments to the transition to the hydrogen economy.

A growing number of countries have committed to accelerate the development of hydrogen and fuel cell technologies to improve their energy security, environmental security and economic security. The IPHE provides an institutional mechanism for partner countries to coordinate their pre-competitive hydrogen research and development programs. Coordinated research through the IPHE is expected to accelerate breakthroughs in material science, standardization of technical codes and standards, and 
the development of manufacturing economies of scale that are necessary for the widespread commercial diffusion of hydrogen technologies.

The IPHE is designed to:

- Identify and promote potential areas of bilateral and multilateral collaboration on hydrogen and fuel cell technologies;

- $\quad$ Analyze and recommend priorities for research, development, demonstration, and commercial utilization of hydrogen technologies and equipment;

- $\quad$ Analyze and develop policy recommendations on technical guidance, including common codes, standards and regulations, to advance hydrogen and fuel cell technology development, demonstration and commercial use;

- Foster implementation of large-scale, long term public-private cooperation to advance hydrogen and fuel cell technology and infrastructure research, development, demonstration and commercial use, in accordance with Partners' priorities;

- Coordinate and leverage resources to advance bilateral and multilateral cooperation in hydrogen and fuel cell technology research, development, demonstration and commercial utilization;

- $\quad$ Address emerging technical, financial, legal, market, socioeconomic, environmental, and policy issues and opportunities related to hydrogen and fuel cell technology that are not currently being addressed elsewhere.

Pursuant to the TOR, two IPHE standing committees were established. The Steering Committee will govern the overall framework, policies and procedures of the IPHE, periodically review the program of collaborative activities, including a review of the organizational structure if necessary, and provide direction to the Secretariat. David K. Garman, Assistant Secretary for Energy Efficiency and Renewable Energy, was elected Chair of the Steering Committee. India, Italy, Japan and Canada were elected as Vice Chairs and are expected to soon report to the Secretariat, the names of their nominees for these positions.

The Implementation and Liaison Committee reports to the Steering Committee. The Implementation and Liaison Committee will review the progress of collaborative projects; identify promising directions for research, development, demonstration, and commercial use; provide technical assessments for policy decisions, pursue international codes and standards and safety protocols, and make recommendations to the Steering Committee on needed actions. Dr. Hanns-Joachim Neef of Germany and Professor Thorsteinn Sigfusson, Chairman of Iceland New Energy, were elected co-Chairs. The European Union, Russia and Brazil were elected as vice chairs and are expected to soon report to the secretariat the names of their nominees for these positions. 
The principle coordinator of the IPHE's communication and activities is the IPHE Secretariat. The Secretariat: 1) organizes the meetings of the IPHE and its committees; 2) arranges special activities such as teleconferences and workshops; 3) receives and forwards new membership requests to the Steering Committee; 4) coordinates communications with regard to IPHE activities and their status; 5) acts as a clearinghouse of information for the IPHE, 6) maintain procedures and responsibilities for key functions that are approved by the Steering Committee; and 7) performs other such tasks as the Steering Committee directs. The focus of the Secretariat will be administrative. The Secretariat will not act on matters of substance except as specifically instructed by the Steering Committee.

The U.S. Department of Energy will serve initially as the IPHE Secretariat unless otherwise decided by consensus of the Partners. This arrangement will be reviewed at two year intervals.

The ministerial meeting commenced on the evening of November 18 at a welcoming reception for over 500 participants on the floor of the international Technology Showcase. Organized by the United States Energy Association and sponsored by Daimler Chrysler, Ford Motor Company, General Motors, Shell Hydrogen and ChevronTexaco, the showcase fostered vigorous public/private interaction between technology developers/vendors, members of the official parties and other private sector companies. In addition to the sponsors, the following companies, associations and research laboratories purchased space in the showcase and organized technology exhibits: Ballard Power Systems; BOC; BP; ECD Ovonics; Fuel Cell Canada; FuelCell Energy, Inc.; H2Gen Innovations; Honda; Hydrogenics Corporation; Hyundai Motor Company; Nissan; Plug Power, Inc.; Sandia National Laboratories; Toyota; and the U.S. Fuel Cell Council. The showcase served as the venue for morning and afternoon breaks as well as evening receptions on November 19 and 20. As a result, exhibitors experienced a constant flow of traffic in the two exhibition areas: an indoor exhibit of stationary fuel cell applications and an outdoor tented exhibit of hydrogen vehicles from seven automobile manufacturers. Anecdotal evidence suggests that equipment sales were initiated at the Technology Showcase.

A Public/Private Dialogue on Moving Forward with the Hydrogen Economy was conducted on November 19. The dialogue was organized to: 1) provide a mechanism for the private sector to offer input to official party members on its research priorities, goals and objectives for the IPHE; and 2) facilitate discussion among the IPHE partners and between the partners and the private sector on the status and future directions of national hydrogen research programs. Secretary of Energy Spencer Abraham opened the dialogue with welcoming remarks, during which he read a letter addressed to the delegates from President Bush. Over 45 senior government officials and leading private sector representatives drawn from each of the IPHE partners participated in the dialogue. Results from the dialogue's policy, research and development and market facilitation tracks were reported out in a special session on the afternoon of November 20 as input to the IPHE Steering and Implementation and Liaison Committees in advance of their initial 
meetings on November 21. The November 19 program concluded with a congressional reception on Capitol Hill for ministers and senior private sector representatives.

The official ministerial meeting was conducted on the morning of November 20. The Secretary of Energy Spencer Abraham opened the meeting with a keynote address. Key points from the address are as follows: 1) the U.S. is committed to the creation of a hydrogen economy as evidenced by the $\$ 1.7$ billion planned investment in hydrogen vehicle and storage technology research and development over the next five years; 2) this commitment stems from both the desire to increase U.S. energy security and because hydrogen presents a clean energy option for the future - total wells-to-wheels fuel consumption of a fuel cell vehicles powered by hydrogen is $50 \%$ less than a comparable gasoline powered vehicle and produces $60 \%$ less greenhouse gas emissions; and 3 ) hydrogen production on the scale necessary to transform the economy will come from sources as diverse as fossil fuels coupled with the sequestration of carbon, renewable energy, and nuclear energy.

Following Secretary Abraham's keynote address, remarks by James Connaughton, Chairman of the White House Council for Environmental Quality, and remarks by Under Secretary of State Paula Dobriansky, ministerial representatives from each partner country provided a 10 minute statement outlining their national hydrogen program and aspirations for the IPHE. Secretary of Transportation Norman Mineta provided an address at the ministerial luncheon. For ministerial statements, see http://www.iphe.net

On the afternoon of November 20, the ministers participated in an exclusive "ride and drive" at the Washington Grand Prix race track organized by the United States Energy Association. The ride and drive afforded ministers and senior staff with the opportunity to test drive hydrogen powered vehicles from from DaimlerChrysler, Energy Conversion Devices, Ford, GM, Hyundai, Honda, Nissan, and Toyota. Several ministers, including Mr. Admowitch of Germany and Minister Sverisdottir of Iceland, also test drove a GM mass transit hydrogen powered passenger bus. The ministerial program concluded on November 20 with a ministers-only dinner hosted by Secretary Abraham at Blair House.

Nearly 200 official party and private sector representatives participated in the initial meetings of the Steering and Implementation and Liaison committees on Friday, November 21.

\section{Comparison of the Actual Accomplishments with the Goals and Objectives of the $\underline{\text { Project }}$}

The goal of the project was to organize and conduct a ministerial meeting to launch the International Partnership for the Hydrogen Economy, a sixteen member nation initiative designed to coordinate and accelerate pre-competitive international cooperative research, development and demonstration hydrogen and fuel cell projects. 
The following goals and objectives were accomplished through the award:

- The IPHE Ministerial Meeting was conducted on November 20, 2003 with official participation from Australia, Brazil, China, European Commission, France, Germany, Iceland, India, Italy, Japan, Korea, Norway, Russia, United Kingdom, United States

- The Terms of Reference were signed by ministerial representatives officially creating the International Partnership for the Hydrogen Economy on November 20,2003

- A Public/Private Dialogue on Moving the Hydrogen Economy Forward was conducted on November 19, 2003 to provide private sector input to the Ministerial meeting conducted the following day. Senior ministry officials and private sector corporate leaders from the hydrogen and fuel cell industry participated in the dialogue.

- The United States Energy Association created and maintained a website for the International Partnership for the Hydrogen Economy: www.iphe.net. The website contains the signed Terms of Reference, a complete set of ministerial and private sector presentations delivered at the Ministerial Conference and Public/Private Dialogue; a members only section for IPHE government representatives to access working documents for the ongoing activities of the partnership; and a photographic archive of the Ministerial Conference

- The United States Energy Association organized a Technology Showcase for leading hydrogen and fuel cell technology vendors as a method of informing the ministerial delegates and members of the public of the potential for hydrogen and fuel cell technology. The showcase was attended by over 500 meeting participants

- The United States Energy Association organized a hydrogen and fuel cell vehicle "Ride and Drive" for ministerial delegates at RFK Stadium in Washington, DC on the afternoon of November 20, 2003. Seven automobile manufacturers provided hydrogen and fuel cell vehicles for the demonstration program designed to provide an opportunity for ministers to handle the technology

- The IPHE Steering Committee and Implementation-Liaison Committee were established. The United States was appointed Chair of the Steering Committee and Iceland and Germany were appointed co-chairs of the ImplementationLiaison Committee

- The US Department of Energy was appointed the Secretariat for the IPHE for its initial two year period of operation 
- The United States Energy Association conducted a US stakeholder briefing update on the activities of the IPHE for private sector participants in June 2004, November 2004 and June 2005. Each briefing was attended by over 100 participants.

- The United States Energy Association produced a set of Hydrogen and Fuel Cell Fact sheets designed to inform the general public of the benefits of, and challenges, advancing the hydrogen economy. Fact sheets on the following subjects were developed:

○ Hydrogen Production

- Hydrogen Storage

○ Fuel Cells

- Regulations, Codes and Standards

○ Socioeconomics of Hydrogen

The IPHE Fact Sheets may be found at www.iphe.net

\section{Products Developed Under this Award}

1) The IPHE website www.iphe.net was created, updated and maintained through this award. The website contains a collection of the Ministerial Conference proceedings, current IPHE working documents developed by the committees and working groups, a calendar of events and a members only section with contact information and committee documents.

2) The United States Energy Association produced a set of Hydrogen and Fuel Cell Fact sheets designed to inform the general public of the benefits of, and challenges, advancing the hydrogen economy. Fact sheets on the following subjects were developed:

○ Hydrogen Production

○ Hydrogen Storage

- Fuel Cells

- Regulations, Codes and Standards

- Socioeconomics of Hydrogen

3) The United States Energy Association published a summary of the initial US stakeholder briefing conducted in June 2004. 


\section{Hydrogen: An Overview}

\section{Overview}

Hydrogen is the most abundant gas in the universe and the simplest element, consisting of one proton and one electron. As a gas, hydrogen does not exist in a natural state on earth. It is always mixed with other elements. Combined with oxygen, it creates water. Combined with carbon, it makes different compounds such as methane, coal, and petroleum today's major fuels.

\section{Hydrogen Production}

Because hydrogen does not exist in a natural state it must be manufactured in an energy intensive process. The energy needed to produce hydrogen can be obtained from many sources, including traditional fossil fuels, nuclear energy and renewable energy sources.

Today, the most common method to produce hydrogen is to employ steam to separate it from carbon found in petroleum and natural gas. When combined with carbon capture and storage technologies designed to reduce carbon dioxide emissions, hydrogen production holds the promise of a plentiful fuel that will help safeguard the world's climate system.

Hydrogen can also be produced by using electricity to separate it from oxygen in water through a process known as electrolysis. The electricity for the electrolysis process can be produced from a variety of energy sources such as oil, coal, natural gas, nuclear energy, and renewable energy sources such as wind power, hydroelectricity, biomass, geothermal, and solar energy. Other less developed and applied methods include thermo and biochemical processes.

\section{The Hydrogen Transformation}

Hydrogen can be utilized to store clean energy that is produced both from traditional fuels using carbon capture and storage technology and from renewable energy sources. Stored as hydrogen or one of its compounds, this clean energy can be moved to where it is needed.

As an energy carrier, hydrogen holds the potential to dramatically transform the ways in which we use energy. It may be utilized to fuel hydrogen-powered vehicles, eventually allowing us to replace traditional automobiles with a clean hydrogen alternative. And, because hydrogen can be stored and transported to where it is needed, it may be used in combination with fuel cells to provide energy in locations not served by the electric power grid and, for stationary applications that require very reliable sources of electricity, such as the information technology industry and medical applications.

Most importantly, because hydrogen can be produced from a variety of energy sources found in most countries, it holds the potential for reducing dependence on imported energy. When produced with clean technologies, it can reduce the emission of carbon dioxide, an important greenhouse gas.

\section{The Challenges}

Before hydrogen can take its place in the global energy picture, many new systems must be built. How will we lower the cost of producing, storing, and transporting hydrogen? How will we increase the durability and reliability, while at the same time, reduce the cost of fuel cells used in transportation and stationary applications? How will consumers access affordable, reliable and safe end use technologies? What international codes and standards will have to be developed to rationalize technology development and ensure its safe deployment? And, how can we educate local officials and emergency response personnel on the potential for, and special requirements of, this technology? 


\section{Hydrogen Storage}

\section{Overview}

Hydrogen has the highest energy content per unit of weight of any known element. It is also the lightest element. As a result, it is characterized by low volume energy density, meaning that a given volume of hydrogen contains a small amount of energy. This presents significant challenges to storing the large quantities of hydrogen that will be necessary in the hydrogen energy economy.

A critical challenge for transportation applications is balancing the need for a conventional driving range $(>480 \mathrm{~km})$ with the vehicular constraints of weight, volume, efficiency, safety, and the cost of on-board hydrogen storage systems. A second set of challenges for transportation applications relate to durability over the performance lifetime of on board storage systems.

To overcome the on-board storage challenge, an alternative may be on-board reformation of higher density fuels such as natural gas, gasoline, and methanol. An added benefit of this approach is that it does not require the development of new distribution infrastructure for pure hydrogen. However, on board reformation of higher density fuels results in the emission of carbon dioxide, although in lesser quantities than the traditional use of these fuels.

\section{Hydrogen Storage Today}

Today, hydrogen for transportation applications is compressed and stored in high-pressure metal and composite storage tanks. Hydrogen is also stored by cooling it to its liquid form and containing it in super-insulated tanks.

- High-pressure tanks can be used to store hydrogen. Today, compressed hydrogen tanks for 5,000 psi ( $35 \mathrm{MPa})$ and 10,000 psi ( 70 $\mathrm{MPa})$ ] have been certified worldwide according to ISO 11439 (Europe), NGV-2 (U.S.), and approved by TUV (Germany) and The HighPressure Gas Safety Institute of Japan (KHK). However, driving ranges for compressed tanks remain inadequate and the energy consumed to compress the hydrogen reduces the efficiency of this storage media. The weight and size of the tanks are also an impediment to this application.

- Liquefied Hydrogen -- The energy density of hydrogen can be improved by storing hydrogen in a liquid state. However, hydrogen losses become a concern and improved tank insulation is required to minimize losses from hydrogen boil-off. In addition, advances in liquefaction efficiencies are required to reduce the energy required to cool and liquefy hydrogen gas.

\section{Future Storage Technologies}

Current research on future storage technology includes:

- Metal hydride technology uses metals and metal alloys to adsorb hydrogen under moderate pressure and temperature, creating hydrides. A metal hydride tank contains a granular metal, which adsorbs hydrogen and releases it with the application of heat. The heat may be supplied as excess heat from a fuel cell. Conventional high capacity metal hydrides require high temperatures $\left(300^{\circ}\right.$ $350^{\circ} \mathrm{C}$ ) to liberate hydrogen, but sufficient heat is not generally available in fuel cell transportation applications.

- Chemical hydride slurries or solutions can be used as a hydrogen carrier or storage medium. The hydrogen in the hydride is released through a reaction with water. Chemical hydride systems are irreversible and require thermal management and regeneration of the carrier to recharge the hydrogen content. An essential feature of the process is recovery and reuse of spent hydride at a centralized processing plant. Research issues include the identification of safe, stable, and pumpable slurries, and the design of the reactor for regeneration of the spent slurry.

- Carbon nanotubes are microscopic tubes of carbon, two nanometers (billionths of a meter) across, that store hydrogen in microscopic pores 
on the tubes and within the tube structures. Similar to metal hydrides in their mechanism for storing and releasing hydrogen, they hold the potential to store a significant volume of hydrogen. However, the amount of storage and the mechanism through which hydrogen is stored in these materials are not yet well-defined.

\section{Challenges}

The principal challenges to improving hydrogen storage technologies relate to increasing their efficiency, size, weight, capacity and, ultimately, their cost. Durability remains an issue, as does the development of unified international codes and safety standards to facilitate safe deployment of commercial technologies.

- Cost. The cost of on-board hydrogen storage systems is currently too high, particularly in comparison with conventional storage systems for petroleum fuels. Low-cost materials and components for hydrogen storage systems are needed, as well as low-cost, high-volume manufacturing methods.

- Weight and Volume. The weight and volume of hydrogen storage systems are presently too high, resulting in inadequate vehicle range compared to conventional petroleum fueled vehicles. Materials and components are needed to allow compact, lightweight hydrogen storage systems that allow driving ranges similar to those available today for light-duty vehicle platforms.

- Efficiency. Energy efficiency is a challenge for all hydrogen storage approaches. The energy required to get hydrogen in and out of storage is an issue for reversible solid-state materials storage systems. In addition, the energy associated with compression and liquefaction must be factored in when considering compressed and liquid hydrogen storage technologies.

- Durability. The durability of some hydrogen storage systems is inadequate. Materials and components are needed that allow hydrogen storage systems with a lifetime in excess of 1,500 refueling cycles.

- Refueling Time. Refueling times are currently too long. There is a need to develop hydrogen storage systems with refueling times of less than three minutes, over the lifetime of the system.

- Codes \& Standards. Applicable codes and standards for hydrogen storage systems and interface technologies, which will facilitate implementation/commercialization and assure safety and public acceptance, have not yet been established. Standardized hardware and operating procedures are required.

IPHE partners are collaborating to reduce the challenges to hydrogen storage technologies and advance toward the hydrogen economy. For more information, please visit www.iphe.net. 


\section{Hydrogen Production and Delivery}

\section{Overview}

The production and transportation of hydrogen in a cost effective, environmentally friendly manner is one of the major challenges to the development of the hydrogen economy.

The production of hydrogen is an energy intensive process. The energy needed to produce hydrogen can be obtained from traditional fossil fuels, nuclear energy and renewable energy sources.

Hydrogen may be produced at large-scale central locations and then transported to multiple end use destinations. Alternatively, it can be produced onsite at small-scale decentralized locations closer to the point of use.

Hydrogen has the highest energy content per unit of weight of any known element. It is also the lightest element. As a result, it is characterized by low volume energy density, meaning that a given volume of hydrogen contains a small amount of energy. This presents significant challenges to transporting, delivering and storing the large quantities of hydrogen that will be necessary in the hydrogen energy economy.

\section{How is Hydrogen Produced?}

About $95 \%$ of the hydrogen we use today comes from processing natural gas. The remainder is produced using electrolysis - a process that splits water into its individual components, hydrogen and oxygen. Some of the specific technologies used to produce hydrogen include:

- $\quad$ Steam reforming converts methane (and other hydrocarbons in natural gas) into hydrogen and carbon monoxide by reaction with steam over a nickel catalyst. The carbon separated from the hydrogen in the reforming process may be captured and sequestered to avoid damage to the environment.

- $\quad$ Electrolysis uses direct electrical current to split water into hydrogen at the negative electrode and oxygen at the positive electrode.

- Steam electrolysis (a variation on conventional electrolysis) uses heat, instead of electricity, to provide some of the energy needed to split water, making the process more energy efficient.

- $\quad$ Thermochemical water splitting uses chemicals and heat in multiple steps to split water into its component parts.

- $\quad$ Photocatalytic systems use special materials to split water using only sunlight.

- $\quad$ Photobiological systems use microorganisms to split water in the presence of sunlight.

- $\quad$ Biological systems use microbes to break down a variety of biomass feedstocks into hydrogen.

- $\quad$ Thermal water splitting uses a very high temperature (approximately $1000^{\circ} \mathrm{C}$ ) to split water.

- Gasification uses heat to break down biomass or coal into a gas from which pure hydrogen can be extracted.

In some countries, major industries such as steel production, petroleum refining and soda production produce excess hydrogen that may be used in the initial stages of the hydrogen economy.

\section{How is Hydrogen Delivered?}

Hydrogen is currently transported by pipeline or by road via cylinders, tube trailers, and cryogenic tankers, with a small amount shipped by rail or barge.

Due to the energy intensive nature and the cost associated with hydrogen distribution via high-pressure cylinders and tube trailers, this method of distribution has a range limited to approximately $200 \mathrm{~km}$.

For longer distances of up to $1,600 \mathrm{~km}$, hydrogen is usually transported as a liquid in super-insulated, cryogenic, over-the-road tankers, railcars, or barges, and then 
vaporized for use at the customer site. This is also an energy intensive and costly process.

Pipelines, which are owned by hydrogen producers, are limited to small areas where large hydrogen refineries and chemical plants are concentrated. A large pipeline system dedicated to transporting large volumes of hydrogen does not yet exist.

\section{The Challenges}

Due to its unique properties - high energy content per unit of weight coupled with low volumetric energy density - the production, transportation and storage of hydrogen presents unique challenges.

Two fundamental questions are how much energy is required to extract hydrogen from naturally occurring, stable hydrogen-rich compounds and whether hydrogen should be produced at large-scale central locations that will require the development of a dedicated infrastructure to store and transport it to end use destinations. Both of these questions demand close evaluation of the related social, economic, and environmental costs and benefits associated with developing a hydrogen production and transportation infrastructure.
In addition, breakthroughs are necessary in material science to reduce the cost of transporting hydrogen over long distances.

Another option is to produce hydrogen at decentralized locations closer to end use applications. This approach requires the examination of other technical and social questions related to the production and storage of hydrogen.

It is likely that hydrogen production, transportation, and storage will use both decentralized and centralized approaches. Developing the infrastructure necessary to produce, store and deliver the large quantities of hydrogen necessary for the future hydrogen economy is one of the major challenges addressed by the IPHE.

The IPHE partners are working to develop the infrastructure necessary to produce, store and deliver the large quantities of hydrogen that will be essential to the future of the hydrogen economy. For more information, please visit the IPHE website at: www.iphe.net. 


\section{Fuel Cells: A Hydrogen Enabling Technology}

\section{Overview}

Fuel cells are one of the key enabling technologies for a future hydrogen economy. They have the potential to replace the internal combustion engine in vehicles and to provide power in stationary and portable power applications.

Fuel cells have several benefits over conventional combustion-based technologies currently used in many power plants and passenger vehicles. They produce much smaller quantities of greenhouse gases. If pure hydrogen is used as a fuel, fuel cells emit only heat and water as a byproduct.

Cost and durability are the major challenges to fuel cell commercialization.

\section{How the Fuel Cell Works}

A fuel cell is a device that generally uses hydrogen and oxygen to create electricity by an electrochemical process. A single fuel cell consists of an electrolyte and two catalyst-coated electrodes. Hydrogen is fed into the anode and oxygen is fed into the cathode. In the case of a PEM Fuel Cell, a catalyst strips electrons from the hydrogen atom. Freed of the electrons, the protons pass through the electrolyte. The electrons take a different path to the cathode creating an electric current that can be utilized. At the cathode, another catalyst rejoins the hydrogen atom, which then combines with oxygen to create a molecule of water. [See Box]

\section{Benefits of Fuel Cells}

- Efficient - Fuel cell vehicles are expected to achieve efficiencies of 40 to 45 percent. On average, an internal combustion engine converts about 15 percent of the energy in gasoline to turn a car's wheels. Fuel cell power plants producing electricity and thermal energy are expected to achieve efficiencies of 80 percent or more when used as combined heat and power plants.

- Clean - The only emission from the tailpipe of a fuel cell vehicle operating on hydrogen is water vapor. Fuel cell vehicles that use an on-board fuel reformer will emit two-thirds less pollution than a gasoline combustion engine. A similar comparison applies to stationary and portable fuel cell applications.

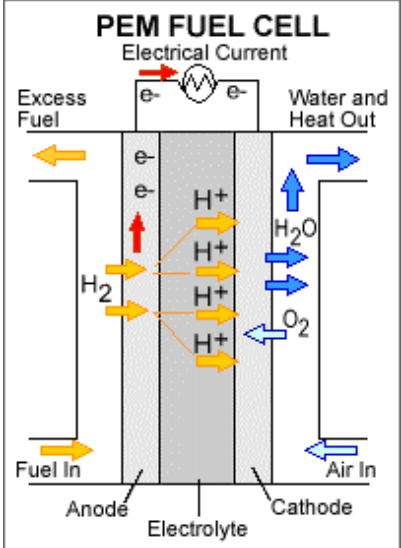

Reliable - Fuel cell systems are highly reliable, which is very desirable for stationary applications that require a high-quality uninterrupted power supply.

- Versatile - Fuel cells can operate on a wide load range and scale from micro production to megawatt production.

\section{Types of Fuel Cells}

- Polymer Electrolyte Membrane (PEM) Fuel Cellsalso called proton exchange membrane fuel cellsdeliver high power density and offer the advantages of low weight and volume, compared to other fuel cells. PEM fuel cells operate at relatively low temperatures, around $80^{\circ} \mathrm{C}$. Low temperature operation allows them to start quickly (less warm-up time) and results in less wear on system components, resulting in better durability. PEM fuel cells are used primarily for transportation applications and some stationary applications. However, this technology requires that a noble-metal catalyst (typically platinum) be used to separate the hydrogen's electrons and protons, adding to system cost. [See Box]

- Alkaline Fuel Cells (AFCs) use a solution of potassium hydroxide in water as the electrolyte and can use a variety of non-precious metals as a catalyst at the anode and cathode. High-temperature AFCs operate at temperatures between $100^{\circ} \mathrm{C}$ and $250^{\circ} \mathrm{C}$.

However, newer AFC designs operate at lower temperatures, roughly $23^{\circ} \mathrm{C}$ to $70^{\circ} \mathrm{C}$. They are frequently used in remote locations and have demonstrated efficiencies near 60 percent in space applications. The disadvantage of this fuel cell type is that it is easily "poisoned" by carbon dioxide $\left(\mathrm{CO}_{2}\right)$. 
- Solid Oxide Fuel Cells use a hard, non-porous ceramic compound as the electrolyte. SOFCs are expected to be around 50-60 percent efficient at converting fuel to electricity. In applications designed to capture and utilize the system's waste heat (cogeneration), overall fuel use efficiencies could top 80-85 percent. Solid oxide fuel cells operate at very high temperatures-around $1,000^{\circ} \mathrm{C}$, removing the need for precious-metal catalyst, thereby reducing cost.).

However, the high temperature results in a slow startup and requires significant thermal shielding to retain heat and protect personnel. The high operating temperatures also place stringent durability requirements on materials.

- Phosphoric Acid Fuel Cells (PAFCs) use liquid phosphoric acid as an electrolyte-the acid is contained in a Teflon-bonded silicon carbide matrix - and porous carbon electrodes containing a platinum catalyst. PAFCs are more tolerant of impurities in fossil fuels that have been reformed into hydrogen than PEM cells. They are 85 percent efficient when used for the cogeneration of electricity and heat, but less efficient at generating electricity alone (37 to 42 percent). PAFCs are typically used for stationary power generation, but some PAFCs have been used to power large vehicles such as city buses. PAFCs require an expensive platinum catalyst, which raises the cost of the fuel cell. A typical phosphoric acid fuel cell costs between $\$ 4,000$ and $\$ 4,500$ per kilowatt to operate.

- Molten Carbonate Fuel Cells (MCFCs) are currently being developed for natural gas and coal-based power plants for electrical utility, industrial, and military applications. MCFCs are high-temperature fuel cells that use an electrolyte composed of a molten carbonate salt mixture suspended in a porous, chemically inert ceramic lithium aluminum oxide $\left(\mathrm{LiAlO}_{2}\right)$ matrix. Since they operate at temperatures of $650^{\circ} \mathrm{C}$ and above, nonprecious metals can be used as catalysts at the anode and cathode to reduce costs. Unlike alkaline, phosphoric acid, and PEM fuel cells, MCFCs don't require an external reformer to convert more energydense fuels to hydrogen. The primary disadvantage of current MCFC technology is durability. The high temperatures at which these cells operate and the corrosive electrolyte used accelerate component breakdown and corrosion, decreasing cell life.

\section{The Challenges}

- Cost. The cost of fuel cell power systems must be reduced before they can be competitive with conventional technologies. Currently the costs for automotive internal combustion engine power plants are about $\$ 25-\$ 35 / \mathrm{kW}$; for transportation applications, a fuel cell system needs to cost $\$ 30 / \mathrm{kW}$ for the technology to be competitive. For stationary systems, the acceptable price point is considerably higher (\$400-\$750/kW for widespread commercialization and as much as $\$ 1000 / \mathrm{kW}$ for initial applications).

- Durability and Reliability. The durability of fuel cell systems has not been established. For transportation applications, fuel cell power systems will be required to achieve the same level of durability and reliability of current automotive engines, i.e., 5,000 hour lifespan $(241,000 \mathrm{~km}$ equivalent), and the ability to function over the full range of vehicle operating conditions $\left(40^{\circ} \mathrm{C}\right.$ to $\left.80^{\circ} \mathrm{C}\right)$. For stationary applications, more than 40,000 hours of reliable operation in a temperature at $-35^{\circ} \mathrm{C}$ to $40^{\circ} \mathrm{C}$ will be required for market acceptance.

- System Size. The size and weight of current fuel cell systems must be further reduced to meet the packaging requirements for automobiles. This applies not only to the fuel cell stack, but also to the ancillary components and major subsystems (e.g., fuel processor, compressor/expander, and sensors) making up the balance of power system.

- Air, Thermal, and Water Management. Air management for fuel cell systems is a challenge because today's compressor technologies are not suitable for automotive fuel cell applications. In addition, thermal and water management for fuel cells are issues because the small difference between the operating and ambient temperatures necessitates large heat exchangers. Another challenge is to develop a reliable and durable membrane that operate in low humidity conditions so as to eliminate the need for complicated water management equipment.

- Improved Heat Recovery Systems. The low operating temperature of PEM fuel cells limits the amount of heat that can be effectively utilized in combined heat and power (CHP) applications. Technologies need to be developed that will allow higher operating temperatures and/or more effective heat recovery systems and improved system designs that will enable CHP efficiencies exceeding $80 \%$. Technologies that allow cooling to be provided from the low heat rejected from stationary fuel cell systems (such as through regenerating desiccants in a desiccant cooling cycle) also need to be evaluated.

\footnotetext{
Partners in the IPHE are collaborating to improve fuel cell technologies to advance toward the hydrogen economy. For more information, please visit www.iphe.net.
} 


\section{Hydrogen Safety Codes \& Standards}

A fundamental challenge to the commercialization of hydrogen energy technologies is the lack of safety information on hydrogen components and systems used in a hydrogen fuel infrastructure. A second challenge is the limited availability of uniform international codes and standards necessary to standardize technology. Internationally accepted codes and standards will be necessary to increase the confidence of local, regional and national officials in the use of hydrogen and fuel cell technology.

\section{Limited Safety Data for Hydrogen Systems}

Hydrogen has been used for years in industrial applications. However, only a small number of the hydrogen and fuel cell technologies, systems and components required for the hydrogen economy are in operation today. Many are in the pre-commercial development phase and are still proprietary. Therefore, only limited data are available on the operational and safety aspects of these technologies.

In addition, the historical data used in assessing safety parameters for the production, storage, transport, and use of hydrogen are now several decades old and will need to be reassessed and re-validated. These safety parameters were established for the industrial use of hydrogen and were not designed for the volume and uses envisioned in the hydrogen economy.

\section{Liability / Insurability Issues}

New technologies not yet recognized in codes and standards may have difficulty in obtaining reasonable rates for insurance, and may not be approved in some cases. The potential for lawsuits and the need to insure facilities and vehicles are serious concerns that could affect the commercialization of hydrogen technologies.

Uniform codes and standards will reduce risks perceived by insurers of new and innovative hydrogen technologies.

\section{International Competitiveness}

Hydrogen and fuel cell codes and standards must be harmonized on an international basis. Internationally accepted safety codes and standards will provide the basis for the economies of scale necessary to commercialize new and innovative hydrogen and fuel cell technology. To facilitate innovation, codes and standards should be performance based, providing the private sector with the freedom to develop technology within the performance standards adopted by government authorities.

\section{Need for Increased Understanding of Hydrogen Systems}

Understanding hydrogen and hydrogen system safety needs is critical for local government officials, fire marshals, and the general public. Emergency personnel must be trained on the special properties of hydrogen and the methods used to respond to accidents involving the use of hydrogen. Developing a set of uniform codes and standards for hydrogen energy systems will increase the confidence of local and municipal officials in permitting the development of hydrogen infrastructure.

The IPHE partners are working together to ensure internationally accepted hydrogen and fuel cell safety codes and standards are developed. For more information, please visit the IPHE website at www.iphe.net. 

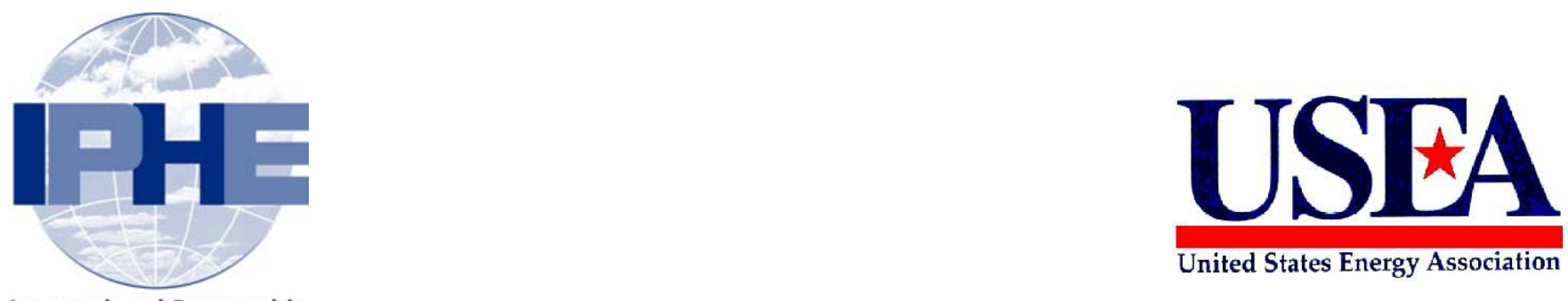

United States Energy Association

International Partnership

for the Hydrogen Economy

\title{
Update Briefing on the International Partnership for the Hydrogen Economy
}

\author{
November 18, 2004 \\ Ronald Reagan Building North Tower Rotunda \\ Washington, DC
}

\begin{abstract}
An interagency team from the U.S. Government (Department of Energy, Department of State, Department of Transportation) conducted an IPHE stakeholder update meeting in Washington, DC on November 18, 2004. This was the second U.S. stakeholder briefing conducted since IPHE was established. Over 70 representatives from the private and public sectors attended the briefing (See Attachment 1). This update focused on recent results of the IPHE, with an emphasis on the development of the Implementation-Liaison Committee Reykjavik Action Plan. The discussion also included a brief review of the progress on items contained in the Steering Committee Beijing Action Plan as well as preparation for the Paris meeting of the Steering Committee in January. The update concluded with a Q\&A session followed by informal networking and lunch.
\end{abstract}

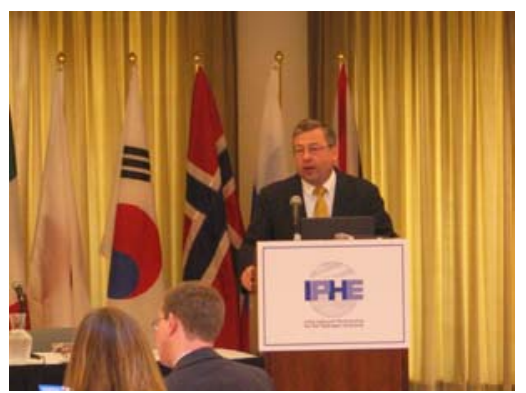

\begin{abstract}
Mr. Barry Worthington, Executive Director of the United States Energy Association opened the briefing by noting that November 18 was the one year anniversary of the IPHE ministerial meeting. He noted that in developing the agenda for the ministerial meeting, particular attention was given to including stakeholder participation through the Public-Private Dialogue sessions. He noted that communication with stakeholders continues to be a high priority for the United
\end{abstract}

States, as emphasized by the two stakeholder briefings organized during the first year of the IPHE.

Mr. Daniel Reifsnyder, Director of the U.S. Department of State Office of Change discussed the role of IPHE in the broader context of international climate change partnerships. These include the GEN IV project, the Carbon Sequestration Leadership Forum, the Earth Observation Summit, the International Partnership for the Hydrogen Economy, and the Methane to Markets initiative.

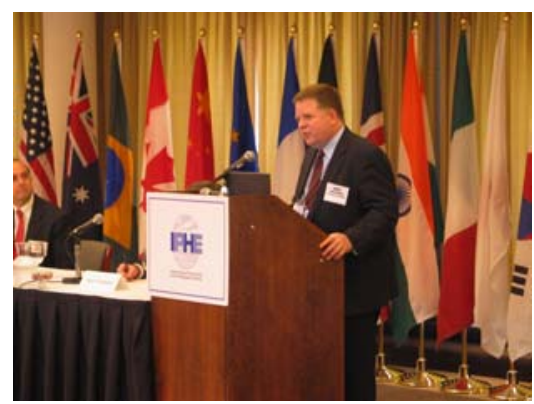

Dr. Robert Dixon, Senior Advisor, U.S. Department of Energy's Office of Energy Efficiency and Renewable Energy and Executive Director, IPHE Secretariat, provided an update on IPHE activities (See Attachment 2). Dr. Dixon emphasized that the mission of the IPHE is to efficiently organize and coordinate multinational research, development and deployment programs that advance the transition to a global hydrogen economy. 
Members of the IPHE include Australia, Brazil, Canada, China, European Commission, France, Germany, Iceland, Japan, India, Italy, Korea, Norway, Russia, United Kingdom, and the United States. Collectively, the partners account for over $\$ 35$ Trillion in GDP, 85\% of world GDP; nearly 3.5 billion people; over $75 \%$ of electricity used worldwide; and $>2 / 3$ of $\mathrm{CO}_{2}$ emissions and energy consumption.

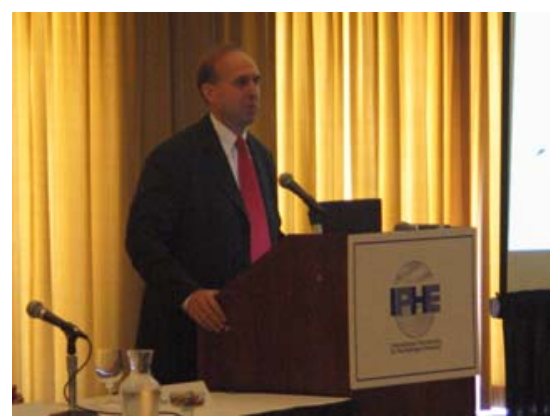

Dr. Dixon discussed the Beijing Action Plan developed in March 2004 at the second meeting of the IPHE Steering Committee. The action plan weaves together the priorities and objectives of the 16 partners. Progress on the plan will be reviewed at the next meeting of the Steering Committee, which will be held in Paris, January 26-27, 2005. Dr. Dixon noted that the IPHE Secretariat is seeking input from the private sector on issues to be discussed at the Paris meeting.

Key elements of the Beijing Action Plan include the identification of an appropriate role for IPHE on international hydrogen and fuel cell codes and standards; the identification of a pathway for stakeholder participation; and the development of a public outreach package. Other actions include convening a meeting of the lead hydrogen and fuel cell research managers of the partners to coordinate RD\&D agendas; compilation of an integrated IPHE partner technology roadmap; and branding international conferences with the IPHE logo and support.

Dr. Dixon reported on the third meeting of the Implementation-Liaison Committee (ILC) conducted in Reykjavik, Iceland in September 2004. Participants at the meeting produced the Reykjavik Action Plan, which is the workplan for the ILC. Activities of the IPHE to be initiated this year include the publication of scoping papers on high priority hydrogen and fuel cell technology research areas; the finalization of a paper on procedures for international collaboration on research and demonstration projects conducted under the IPHE; and convening a workshop to prioritize collaborative research on fuel cells. Other items from the action plan include establishing task forces on international codes and standards and on the socioeconomics of hydrogen; the development of an interactive digital world atlas of hydrogen and fuel cell projects; and developing criteria and procedures for labeling hydrogen and fuel cell RD\&D projects as IPHE projects.

Dr. Dixon provided a demonstration of the first iteration of the interactive digital world atlas of hydrogen and fuel cell demonstration projects. He thanked the US Fuel Cell Council for providing initial data for the atlas. When completed, the atlas will provide an overview and brief technical information on each of over 250 hydrogen and fuel cell demonstration projects with links to project web sites for further information. The atlas will continue to be a living product of IPHE, with new projects continually added and new information updated for the existing projects.

Lastly, Dr. Dixon reported that the IPHE website has migrated to a new address: www.iphe.net. Information contained on the site includes minutes, presentations and member statements from the Steering Committee and ILC meetings. The site contains a worldwide calendar of hydrogen and fuel cell meetings and conferences. The site also contains links to the websites for hydrogen and fuel cell policy and research programs for each of the IPHE partners.

Mr. Samuel Bonasso, Deputy Administrator of the U.S. Department of Transportation's Research and Special Programs Administration (RSPA) provided an overview of RSPA and DOT's role in regulating the transportation of hazardous materials and vehicle safety. He also commented on the potential role of IPHE in international hydrogen codes and standards. (See Attachment 3 for Mr. Bonasso's remarks.) Mr. Bonasso noted that safety codes, standards and regulations must be 
developed concurrently with the pace of commercially available vehicles. He further noted that regulations are the final enablers for commercial introduction. They protect both the public and industry. They cover both the vehicles and stationary applications, and the production, transport, and distribution systems as well.

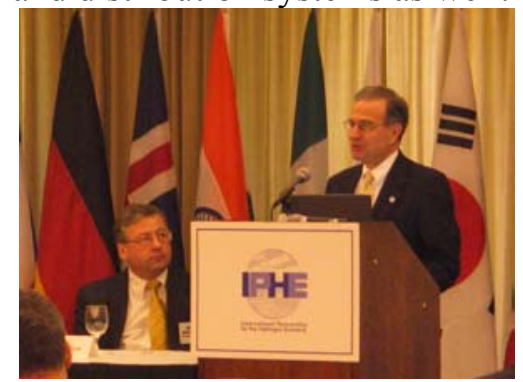

Mr. Bonasso stated that in the U.S. finalizing regulations typically takes up to the 10-15 years. During this time a comprehensive database must be created, testing occurs, and procedures are developed, modified and finalized. He noted that while IPHE is not a standard setting organization, it can play a role in setting up consistent mechanisms and definitions for interpreting data.

Mr. Bonasso mentioned that one of the priority items resulting from the IPHE Steering Committee meeting in Beijing, May 2004, was for the Implementation-Liaison Committee to establish a task force to address research and testing needed to support harmonized codes, standards and Global Technical Regulations.

Following Mr. Bonasso, Barry Worthington moderated a Question and Answer session.

Question Posed by Bill Craven, Daimler Chrysler:

What progress has been made on the Beijing Action Plan?

Response Provided by Robert Dixon, U.S. Department of Energy:

The IPHE has made remarkable progress in bringing together a group of 16 nations each at different stages of development in their hydrogen and fuel cell research programs and with sometimes differing objectives. The Beijing Action Plan represents the first attempt at providing common work products from this diverse group. Since its development in March, the IPHE has enhanced its public outreach program through its new website. It has taken your input from the first stakeholder meeting conducted in Washington, DC to begin drafting a pathway for stakeholder participation and it is in the process of organizing two major industry conferences on hydrogen storage and hydrogen production from renewable energy sources. I encourage you to continue to visit the website to monitor our progress.

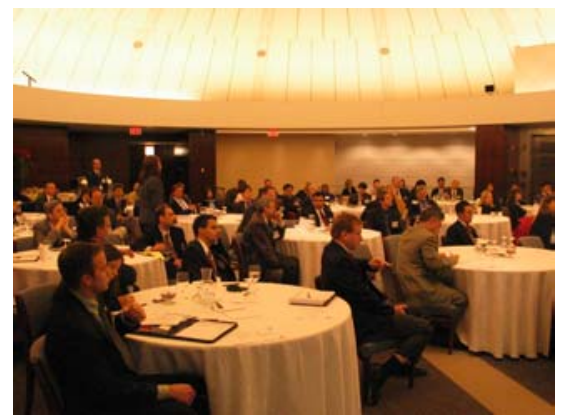

Question Posed by Barney Rush, H2 Gen Innovations: What Can the Private Sector do to Support IPHE?

Response Provided by Robert Dixon, U.S. Department of Energy:

There are many opportunities to participate in the IPHE activities. There are frequent opportunities to participate in study tours and diplomatic missions such as the recent meetings in Italy focusing on the development of hydrogen industrial parks and in Brazil, where we learned of the progress being made in the development of the Brazilian

hydrogen roadmap. Please visit with the IPHE Secretariat and we will provide detailed counsel and guidance.

Response Provided by Samuel Bonasso, U.S. Department of Transportation:

We would like to hear from you regarding what governments can do among IPHE nations to reduce the barriers to commercialization of this technology.

Response Provided by Daniel Reifsnyder, U.S. Department of State:

Please do not let us get too far down the road before we hear from you. We are coordinators among governments. We need input from the private sector. 
Question Posed by Tim Richards, GE:

Is there an effort for stationary energy similar to the effort that is being initiated on codes and standards for transportation applications?

Response Provided by Robert Dixon, U.S. Department of Energy:

Among the 16 partners, there are differing priorities and objectives. Some of the partners are focusing on stationary applications more intensively than others. At the next meeting of the Implementation-Liaison Committee, which will be conducted in March in Brazil, a focus will be on IPHE activities to support the development of stationary technologies.

Question posed by Peter Rhodes, Inside Washington Publishing: Can you tell me when you see occurring the transition from experimental research, development and demonstration projects to a more commercial approach to the testing of vehicles that will require DoT approved codes and standards?

Response by Samuel Bonasso, U.S. Department of Transportation:

We are looking at the 2006-2010 timeframe for real testing of hydrogen and fuel cell vehicles that will be done together with the auto industry.

\section{Question Posed by Bob Rose, U.S. Fuel Cell Council:}

How can we do a better job at coordinating meetings with industry meetings to ensure more industry participation?

Response Provided by Robert Dixon, U.S. Department of Energy:

We are always looking to co-locate meetings with industry meetings. The upcoming meeting of the Implementation-Liaison Committee will be conducted in coordination with the first ever PanSouth America hydrogen meeting. The Steering Committee meeting to be held in Japan this spring is being scheduled to coincide with a major meeting of the Japanese auto industry.

Response Provided by Daniel Reifsnyder, U.S. Department of State:

You may recall that the first meeting of the ILC was conducted in Beijing to coincide with a major hydrogen meeting being conducted in Beijing. We will continue to look for ways in which we can co-locate meetings to provide opportunities for industry participation.

Response Provided by Barry Worthington, U.S. Energy Association:

Remember, you can always contact the Secretariat to have a speaker from the IPHE address an industry meeting.

Comment Provided by Krishna Sapru, Energy Conversion Devices:

Over the course of only one year, I believe IPHE is to be commended for what it has accomplished.

The briefing concluded with networking and lunch. 


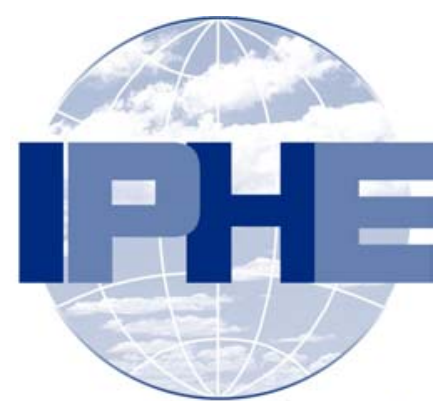

International Partnership for the Hydrogen Economy

Update Briefing on the International Partnership for the Hydrogen Economy

Attachment 1:

Participant List 


\section{INTERNATIONAL PARTNERSHIP FOR THE HYDROGEN ECONOMY \\ ** STAKEHOLDER BRIEFING** \\ Thursday, November 18, 2004 \\ 11:00am-1:30pm}

$\begin{array}{llll}\text { Avraham } & \text { Arbib } & & \text { Ministry of Natural Infrastructure of Israel } \\ \text { Carol } & \text { Bailey } & & \text { U.S. Department of Energy } \\ \text { Tiffany } & \text { Baker } & & \text { U.S. Department of Justice } \\ \text { Kimberly } & \text { Ballou } & \text { European \& Asian Affairs } & \text { U.S. Department of Energy } \\ \text { Giulia } & \text { Bisconti } & & \text { U.S. Department of Energy } \\ \text { Judith } & \text { Blanchard } & \text { Federal Relations Manager } & \text { ChevronTexaco } \\ \text { Sarah } & \text { Blandford } & \text { Program Coordinator } & \text { U.S. Energy Association } \\ \text { Samuel } & \text { Bonasso } & & \text { U.S. Department of Transportation } \\ \text { Chris } & \text { Bordeaux } & & \text { U.S. Department of Energy } \\ \text { Ethan } & \text { Brown } & \text { Advisor, Industry \& Government Affairs } & \text { Ballard Power Systems } \\ \text { Walt } & \text { Buchholtz } & \text { Sr. Environmental Advisor } & \text { Exxon Mobil Corporation } \\ \text { Patrick } & \text { Calpin } & \text { Government Relations } & \text { Honda North America } \\ \text { Ben } & \text { Cannon } & \text { Director, Federal Affairs } & \text { BP America, Inc. } \\ \text { Tom } & \text { Carpenter } & \text { Associate Lobbyist } & \text { Wexler \& Walker Public Policy Associates } \\ \text { Doug } & \text { Carroll } & \text { Advanced Technologies and Programs } & \text { GE Energy }\end{array}$




\section{INTERNATIONAL PARTNERSHIP FOR THE HYDROGEN ECONOMY \\ ** STAKEHOLDER BRIEFING ${ }^{* *}$ \\ Thursday, November 18, 2004 \\ 11:00am-1:30pm}

\begin{tabular}{|c|c|c|c|}
\hline Nancy & Checklick & Lead Environment Analyst & Science Applications International Corporation \\
\hline Prashant & Chintawar & Director, Government Marketing & Nuvera Fuel Cells Inc. \\
\hline Raj & Choudhury & Manager, Government Relations & General Motors \\
\hline Keith & Cole & Director, Legislative \& Regulatory Affairs & General Motors \\
\hline Jeff & Crater & Manager, Government Programs & BWXT Technologies Inc. \\
\hline William & Craven & Manager, Regulatory \& Technical Affairs & Daimler Chrysler \\
\hline Erin & Cready & Analyst & Sentech \\
\hline James & Cross & Vice President & Nuvera Fuel Cells Inc. \\
\hline Boryana & Damyanova & International Law and Policy & GE Corporate \\
\hline Mary-Rose & de Valladares & Secretariat & IPHE Hydrogen Implementing Agreement \\
\hline William & Derasmo & Partner & Troutman Sanders LLP \\
\hline Barbara & DeRosa Joynt & & U.S. Department of State \\
\hline Robert & Dixon & & U.S. Department of Energy \\
\hline Rob & Donovan & Program Manager & U.S. Energy Association \\
\hline Albert & Doub & Senior Program Coordinator & U.S. Energy Association \\
\hline
\end{tabular}




\section{INTERNATIONAL PARTNERSHIP FOR THE HYDROGEN ECONOMY \\ ** STAKEHOLDER BRIEFING** \\ Thursday, November 18, 2004 \\ 11:00am-1:30pm}

\begin{tabular}{|c|c|c|c|}
\hline Benoit & Dreux & Vice President & Electricite de France International N. America \\
\hline Carrie-Lee & Early & Counsel & House Committee - Energy Subcommittee \\
\hline Jennifer & Gangi & Program Director & Fuel Cells 2000 \\
\hline Nancy & Garland & Technology Development Manager & U.S. Department of Energy \\
\hline Leo & Grassilli & AFV Advisor & Department of Navy \\
\hline Thomas & Gross & Associate & IF, LLC \\
\hline David & Haberman & & IF, LLC \\
\hline Walter & Hall & Senior Energy Advisor & U.S. Agency for International Development \\
\hline John & Hammond & Program Coordinator & U.S. Energy Association \\
\hline Craig & Hansen & Manager, Government Programs & BWXT Technologies Inc. \\
\hline Evan & Harrje & Energy Policy Analyst & Aramco Services Company \\
\hline Debbie & Hinz & & U.S. Department of Transportation \\
\hline Shelly & Irby & Senior Program Coordinator & U.S. Energy Association \\
\hline Philippe & Jamet & Attache for Science \& Technology & Embassy of France \\
\hline W. Mark & Jordan & Manager, Energy \& Environmental Division & IRG \\
\hline
\end{tabular}




\section{INTERNATIONAL PARTNERSHIP FOR THE HYDROGEN ECONOMY \\ ** STAKEHOLDER BRIEFING** \\ Thursday, November 18, 2004 \\ 11:00am-1:30pm}

$\begin{array}{llll}\text { Michael } & \text { Kearns } & \text { Director, Public Affairs } & \text { National Ocean Industries Association } \\ \text { Emily } & \text { Kennedy } & \text { Research Officer for the Counsellor } & \text { Embassy of Australia } \\ \text { Bob } & \text { Kripowicz } & \text { President } & \text { Milestone Consulting, LLC } \\ \text { Ellen } & \text { Kuo } & \text { Government Relations Specialist } & \text { BWXT Technologies Inc. } \\ \text { Erin } & \text { Lane } & \text { Manager, Government Relations } & \text { Plug Power } \\ \text { Ivan } & \text { Lebedev } & \text { Senior Correspondent } & \text { ITAR-TASS News Agency of Russia } \\ \text { John C. } & \text { Lee } & \text { Research Scientist } & \text { Brookhaven National Lab } \\ \text { Chen } & \text { Lei } & \text { First Secretary } & \text { Embassy of China } \\ \text { Nanci } & \text { Lizzel } & & \text { IF, LLC } \\ \text { Charles } & \text { Llenza } & \text { International Team LAC Coordinator } & \text { U.S. Department of Energy } \\ \text { Robert } & \text { Manning } & & \text { U.S. Department of State } \\ \text { Tadashi } & \text { Mano } & \text { Manager, Power System Engineering } & \text { Tokyo Electric Power Company } \\ \text { Younes } & \text { Masiky } & \text { Project Manager } & \text { Sentech } \\ \text { Matthew } & \text { Mendis } & \text { Corporate VP, Energy \& Env Management Div. } & \text { International Resources Group } \\ \text { Tyler } & \text { Messa } & \text { International Trade Analyst } & \text { Embassy of Korea }\end{array}$




\section{INTERNATIONAL PARTNERSHIP FOR THE HYDROGEN ECONOMY \\ ** STAKEHOLDER BRIEFING** \\ Thursday, November 18, 2004 \\ 11:00am-1:30pm}

\begin{tabular}{|c|c|c|c|}
\hline Michael & Mills & & U.S. Department of Energy \\
\hline William & Mitchell & Vice President & Nuvera Fuel Cells Inc. \\
\hline Renato & Moura & Senior Market Analysis & Bechtel Power \\
\hline Hiroshi & Nishida & Director, Washington Office & JASIC \\
\hline Dae Kyu & Park & Second Secretary & Embassy of Korea \\
\hline Joseph & Perkowski & Senior Advisor Engineer/Scientist & Idaho National Eng \& Env Lab \\
\hline Duane A. & Pfund & Assistant International Standards Coordinator & U.S. Department of Transportation \\
\hline Will & Polen & Program Manager & U.S. Energy Association \\
\hline Anthony & Rachall III & Commissioner & DC Public Service Commission \\
\hline Anita & Ragan & Regulatory Affairs Associate & Tokyo Electric Power Company \\
\hline Lisette & Ramcharan & Counselor, Science \& Technology & Embassy of Canada \\
\hline Carol & Read & & U.S. Department of Energy \\
\hline Daniel & Reifsnyder & & U.S. Department of State \\
\hline B. & Reutov & & $\begin{array}{l}\text { Federal Agency on Science and Innovations of } \\
\text { the Russian Federation }\end{array}$ \\
\hline Chemin & $\operatorname{Rim}$ & Commercial Counselor & Embassy of Korea \\
\hline
\end{tabular}




\section{INTERNATIONAL PARTNERSHIP FOR THE HYDROGEN ECONOMY \\ ** STAKEHOLDER BRIEFING** \\ Thursday, November 18, 2004 \\ 11:00am-1:30pm}

\begin{tabular}{|c|c|c|c|}
\hline Randall B. & Roe & Vice Chairman & Burns \& Roe Enterprises, Inc. \\
\hline Peter & Rohde & Chief Editor & Inside Washington Publishers \\
\hline Robert & Rose & Executive Director & U.S. Fuel Cell Council \\
\hline Barney & Rush & CEO & H2Gen Innovations \\
\hline Jerry & Russel & Manager, Environment \& Energy & Ford Motor Company \\
\hline Arthur & Rypinski & Energy Specialist, Office of the Secretary & U.S. Department of Transportation \\
\hline Krishna & Sapru & & Energy Conversion Devices, Inc. \\
\hline Yoshiki & Sekiya & Senior Manager & Nissan North America, Inc. \\
\hline Rajat & Sen & President & Sentech \\
\hline Patrick & Serfass & Technical and Program Development Coordinator & National Hydrogen Association \\
\hline Hideo & Shindo & Chief Representative, Washington DC Office & NEDO \\
\hline Victor & Shulepov & Counselor, Science \& Technology & Embassy of Ukraine \\
\hline Minister Marcelo & Sima & Minister & Embassy of Argentina \\
\hline Jon W. & Slangerup & President \& CEO & Stuart Energy Systems Corporation \\
\hline Dan & Spearling & Director & University of California Davis \\
\hline
\end{tabular}




\section{INTERNATIONAL PARTNERSHIP FOR THE HYDROGEN ECONOMY \\ ** STAKEHOLDER BRIEFING** \\ Thursday, November 18, 2004 \\ 11:00am-1:30pm}

$\begin{array}{lll}\text { Megumi } & \text { Suzuki } & \text { Research Specialist } \\ \text { Jonathan } & \text { Temple } & \text { Senior Energy Policy Analyst } \\ \text { Rob } & \text { Tomiak } & \text { Energy Program Manager } \\ \text { Thomas } & \text { Triller } & \text { First Secretary } \\ \text { Kathleen } & \text { Winn } & \text { President } \\ \text { Barry } & \text { Worthington } & \text { Executive Director }\end{array}$

Toyota Motor North America, Inc.

Embassy of United Kingdom

U.S. Department of Defense

Embassy of Germany

Kathleen Winn Assc.

U.S. Energy Association 


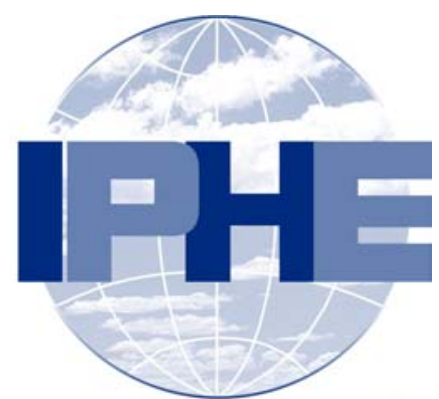

International Partnership for the Hydrogen Economy

Update Briefing on the International Partnership for the Hydrogen Economy

Attachment 2:

Robert K. Dixon, Ph.D

Presentation 


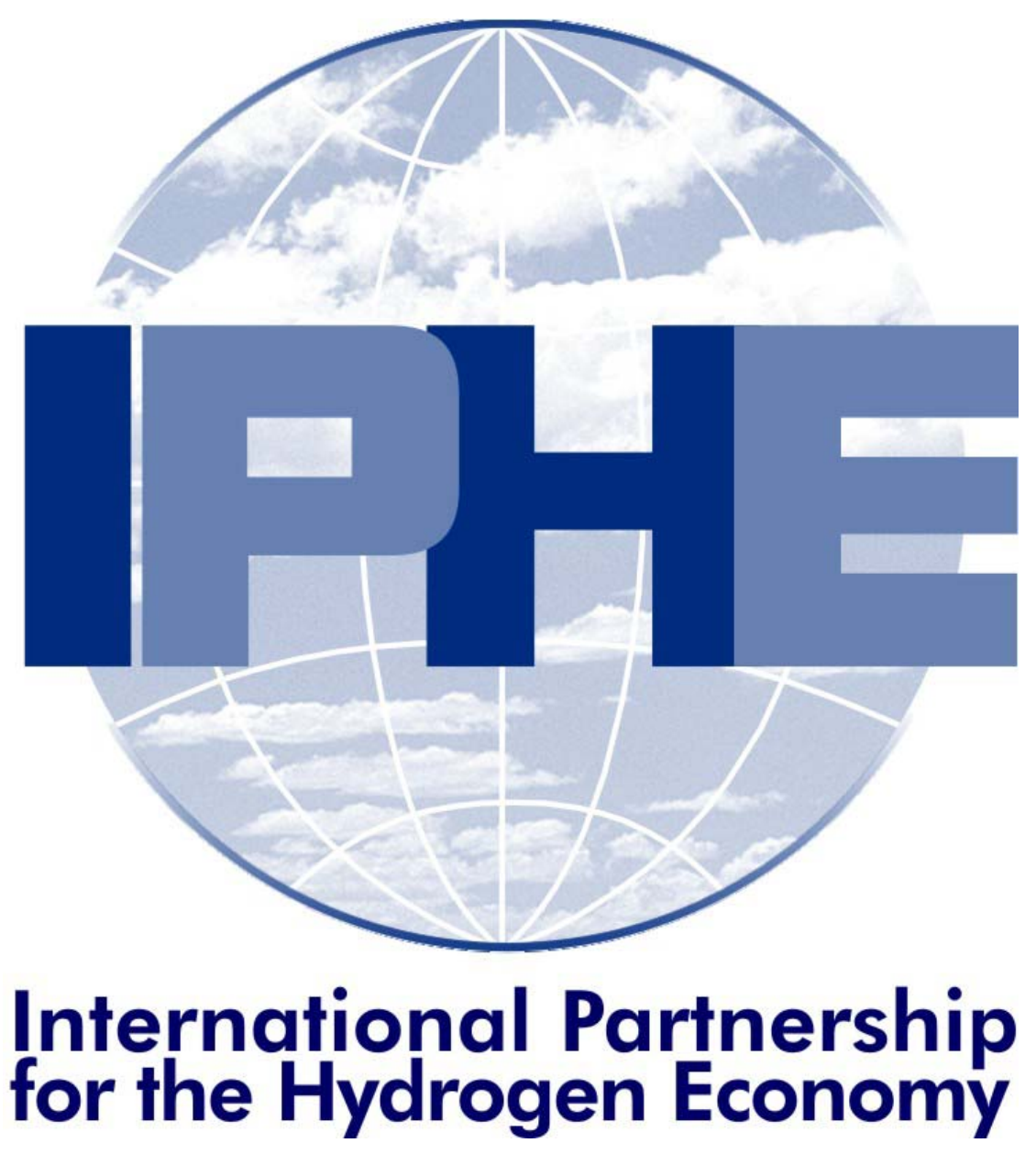




\section{IPHE Goal}

Efficiently organize and coordinate multinational research, development and deployment programs that advance the transition to a global hydrogen economy.

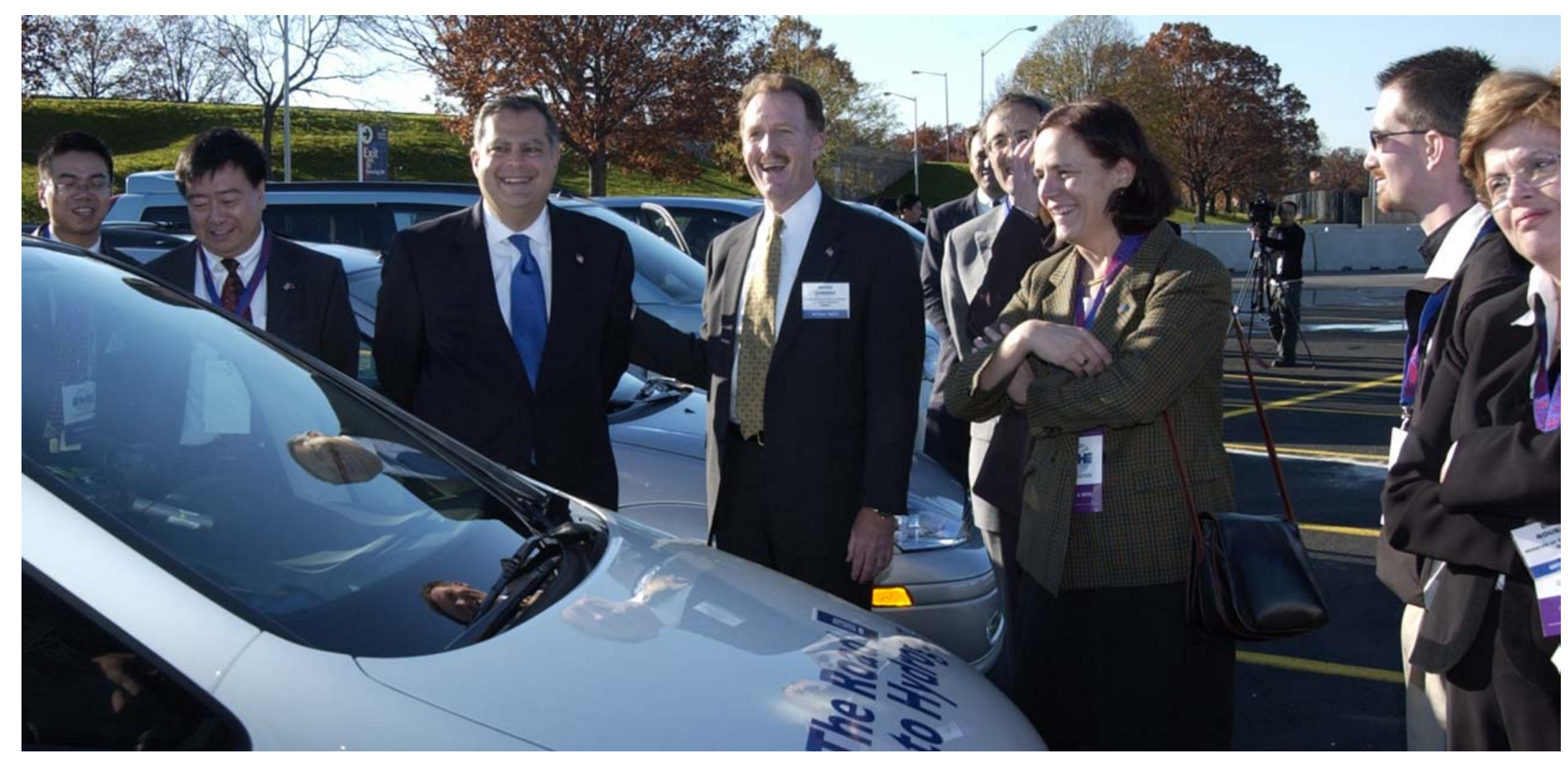




\section{IPHE Partners}
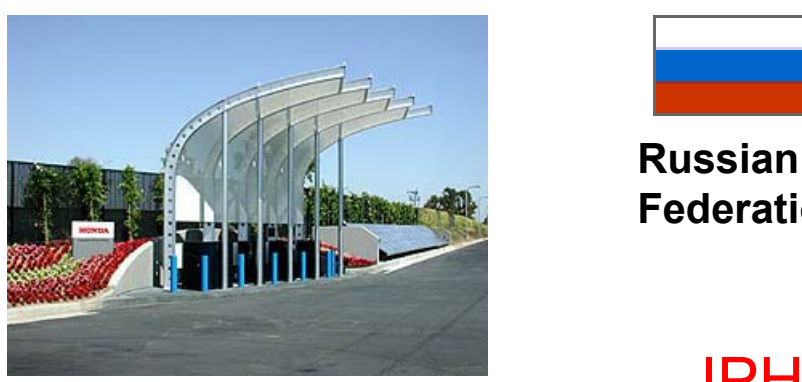

Russian Federation

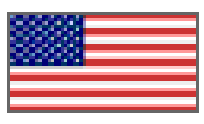

USA

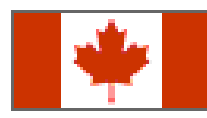

Canada

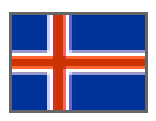

Iceland

\section{$\underline{\text { IPHE Partners' Economy: }}$}

China

(0)

India

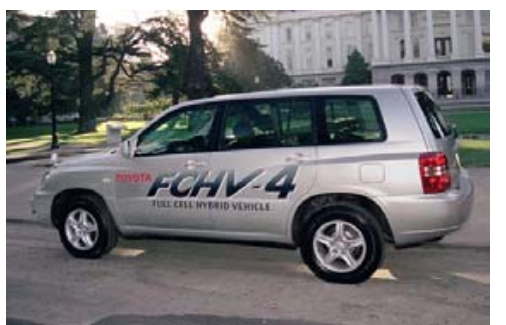

- Over \$35 Trillion in GDP, 85\% of world GDP

- Nearly 3.5 billion people

- Over $75 \%$ of electricity used

Republic of

Korea worldwide;

- > 2/3 of $\mathrm{CO}_{2}$ emissions and energy consumption
European

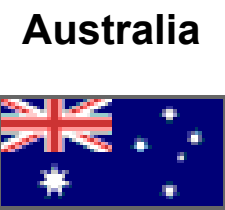

Brazil

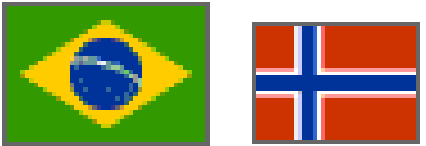

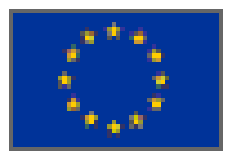

United Kingdom

France

Germany

Italy
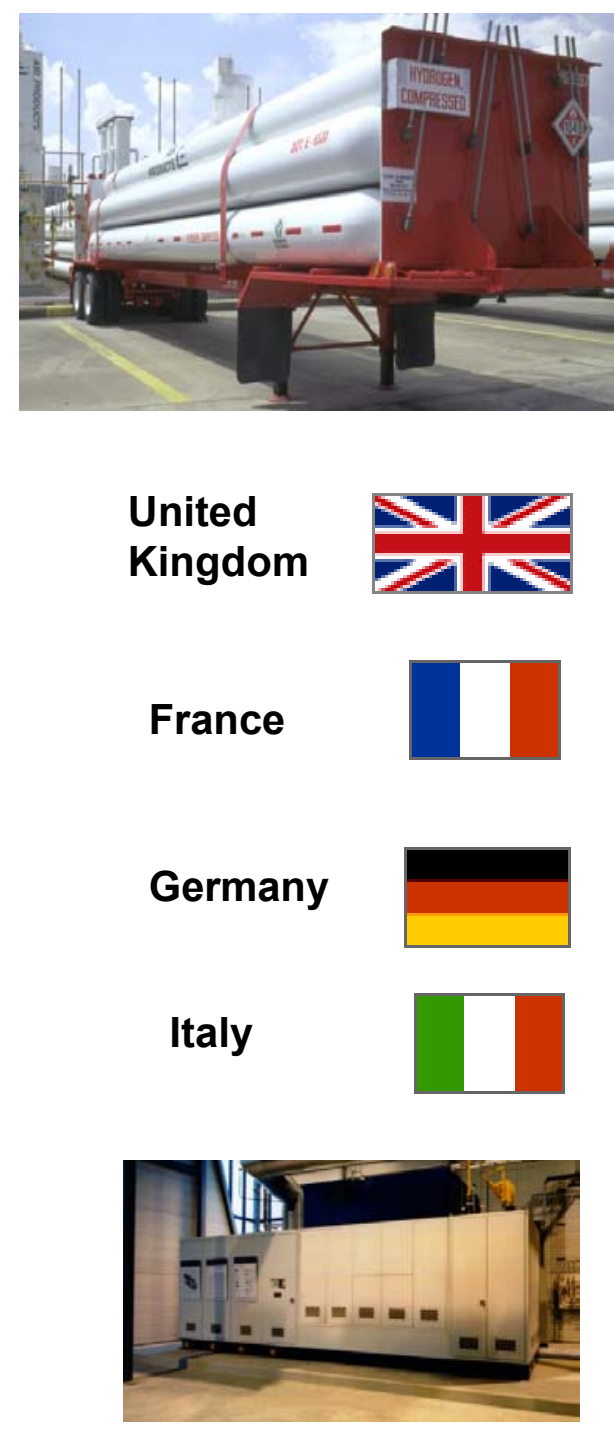


\section{Steering Committee}

$>$ Held in Beijing, China - May 2004

$>$ Initiated the Beijing Action Plan:

* Develop Steering Committee Workplan

- Identify appropriate role for IPHE in Codes and Standards work

* Identify pathway forward for stakeholder participation

* Develop IPHE communication and outreach package

* Convene a meeting of the R\&D managers on IPHE Partners

* Compile an integrated IPHE hydrogen roadmap

* Organize international conferences

$>$ Next meetings:

* France (26 - 28 Jan. '05);

* Japan (May '05); Iceland (November '05);

* Canada (April '06), and Brazil (Fall '06). 


\section{Implementation-Liaison Committee}

$>2^{\text {nd }}$ meeting in Germany, March 2004

$>$ High Priority Activities

* Hydrogen Production

* Hydrogen Storage

* Fuel Cells

* Codes and Standards

* Socio-economics

$>$ Developing national hydrogen R\&D Roadmaps

$>$ Organizing international workshops

* Storage: Lucca, Italy - Summer 2005

- Renewable Production, October 2005

$>$ Next Meetings

* Brazil (March '05); China (Sept. '05) 


\section{Implementation-Liaison Committee, continued}

$>3^{\text {rd }}$ Meeting in Iceland, September 2004

$>$ Initiated the 14 Point Reykjavik Action Plan:

- Publication of Scoping Papers on High Priority Activities

* Finalize Paper on Collaborative Projects under the IPHE

- Conduct International Conference on Hydrogen Production from Renewable Energy Sources

* Conduct an International Workshop to Prioritize Collaborative Fuel Cell Research Projects

- Establish Task Force Focusing on Socioeconomics of Hydrogen

* Conduct an International Conference on Hydrogen Storage

- Establish a Safety, Codes and Standards Task Force 


\section{Implementation-Liaison Committee, continued}

$>$ Reykjavik Action Plan, Continued:

* Support Enhanced Communication and Outreach

* Hydrogen Education

- Participation in International Conferences and Workshops

* World Atlas on Hydrogen and Fuel Cell Demonstration Projects

* Development of IPHE Roadmap

* Meeting of the IPHE R\&D Managers

* Labeling IPHE Projects 


\section{Contacts}

\section{E-Mail: IPHE@EE.DOE.GOV}

Robert Dixon

U.S. Department of Energy

202/586-1394

robert.dixon@ee.doe.gov

Michael Mills

U.S. Department of Energy

202/586-6653

michael.mills@ee.doe.gov
Christopher Bordeaux

U.S. Department of Energy

202/586-3070

christopher.bordeaux@ee.doe.gov

Debbie Hinz

U.S. Department of Transportation 202/366-6945

deborah.hinz@RSPA.dot.gov

\section{Internet: http://www.iphe.net}




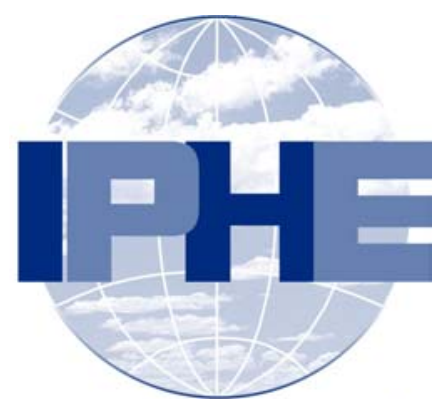

International Partnership for the Hydrogen Economy

Update Briefing on the International Partnership for the Hydrogen Economy

\section{Attachment 3:}

Samuel G. Bonasso

Remarks 


\author{
Remarks \\ As Prepared For Delivery By \\ Samuel G. Bonasso, Deputy Administrator \\ Research and Special Programs Administration (RSPA) \\ Update on the International Partnership \\ For the Hydrogen Economy \\ Washington, DC \\ November 18, 2004
}

Good afternoon.

It is a pleasure to be here today representing the U.S. Department of Transportation and, in particular, DOT's Research and Special Programs Administration.

RSPA, as we call it today, is the Federal agency that regulates, inspects, and enforces the safety codes and standards for hazardous materials in transportation. Over the next few months we will transition to two organizations .... one focused on research and innovative technology, and the other to better regulate and manage hazardous materials in transportation. Hydrogen is expected to be a considerable subject matter for both of these organizations. 
At present, RSPA's safety authority includes the 800,000 hazmat shipments transported daily by rail, highway, vessel and air. Petroleum products currently account for over $80 \%$ of the roughly 3.1 billion tons of hazardous materials shipped in the U.S. annually. Hazardous liquid and gas commodities - fully two-thirds of the nation's petroleum products -- travel through the $\mathbf{2 . 3}$ million miles of pipelines traversing the nation. These pipelines will be affected by the transition to a hydrogen economy.

As hydrogen replaces or supplants a petroleum-based economy, it will have a potentially profound impact on our hazardous material transportation guidelines. We are here today to plan for this eventuality.

At the IPHE Ministerial conference in November, 2003, Transportation Secretary Mineta committed the Department of Transportation to fully support President Bush's Hydrogen Fuel Initiative.

He emphasized that DOT has the responsibility to the American public to ensure the safety of all hydrogen fuel-based vehicles, fueling infrastructure, and hydrogen commodities in transport. We will fulfill this responsibility through the development and enforcement of safety standards, codes, and regulations. Without these standards, codes, and regulations there will be no mass production of hydrogen fuel vehicles to operate on our nation's highways. 
Ultimately, the market will determine the commercial success of hydrogen as a fuel. And the public will demand that hydrogen-powered products are safe and cost efficient.

Ensuring safety in a diverse and complex system requires adequate lead-time, anticipation of worst case scenarios, demonstrations, and repeated testing. The Department of Transportation is already faced with requests to review and approve exemptions for novel designs to transport hydrogen.

Among these designs are Plastic-lined, carbon fiber-wrapped cylinders capable of service pressures ranging from 7,300 up to 13,000 pounds per square inch, and use of metal and chemical hydride technology to store and transport hydrogen.

Cylinder, tank, or pipeline failure due to hydrogen embrittlement;

Changes in testing and service life;

Different packaging failure modes and consequences; and,

A host of other technical issues confront us as we move to a hydrogen economy.

Ensuring that hydrogen systems and fuel cell powered vehicles provide a level of safety comparable to other vehicles currently in use requires a substantial research effort. 
The Department of Transportation supports advanced hydrogen research that is looking at performance characteristics of technologies and systems. We are involved in developmental demonstrations to understand hydrogen's energy capabilities and hazards.

This is ongoing laboratory work today that is preparing for the safe, wide-spread use of hydrogen tomorrow.

झpresent, the Research and Special Programs Administration is actively contributing to a blueprint to deploy a hydrogen energy transportation infrastructure in the State of California by the year 2010. Governor Schwarzenegger's California Hydrogen Highway project is an ambitious test pilot - a model for a functioning, publicly accessible hydrogen refueling network throughout the "Golden State."

I'm sure you all know that a hydrogen refueling station was opened in Washington, D.C. last week.

The fueling station includes an information center where visitors can read about hydrogen, watch videos, and view a model of the kind of hydrogen storage tank used in today's demonstration vehicles.

The station also will provide important research on the operation of vehicles and hydrogen refueling. 
While these two initiatives seek to solve the infrastructure availability problem, they also reinforce the notion that hydrogen fueled vehicles will be available. They also present an opportunity to begin educating the public.

It is extremely important that we all realize that safety codes, standards, and regulations must be developed concurrently with the pace of commercially available vehicles.

Regulations are the final enablers for commercial introduction. They protect both the public and industry. They cover both the vehicles and stationary applications, and the production, transport, and distribution systems as well.

The ambitious goals set forth by President Bush, the IPHE, and industry estimate commercial deployment by approximately 2015. Regulations need to be in place before then to ensure that the vehicles have been adequately tested before they are offered to the general public.

Consequently there must be a foundation for these regulations. There must be consensus codes and standards, and the research to support them in an authoritative and credible manner. 
In the U.S., the process of finalizing regulations typically takes 10-15 years. It takes this long to build a comprehensive experiential database through vigilant testing and the subsequent development, modifications, and so on.

Today, in particular, we are going to discuss what the IPHE can do to further global safety codes, standards and regulations.

Although not a standards setting organization, the IPHE can play a pivotal role in setting up consistent mechanisms and definitions for interpreting data collections.

Creating a standard language and metric for data collection will make experiential information sharing more valuable. It will help to inform the establishment of a common global template. Safety, maintenance, cost, and performance data from initiatives worldwide can then truly support a global initiative and still have independent value for each of the individual partners.

One of the priority items resulting from the IPHE Steering Committee meeting in Beijing, May 2004, was for the Implementation-Liaison Committee to establish a task force to address research and testing needed to support harmonized codes and standards and Global Technical Regulations. 
The Steering Committee will use the findings and recommendations of the Implementation-Liaison Committee to identify an appropriate role for the IPHE in international codes and standards work.

The IPHE has agreed they should not duplicate any ongoing activities, but identify gaps, provide guidance through agreed-upon projects and provide a forum for advancing common regulation, code and standards, and safety protocols.

The IPHE recognizes there are a number of ongoing international activities on regulations, codes and standards for the production, transportation and use of hydrogen.

However, the IPHE is not aware of an up-to-date comprehensive description of those activities.

Therefore, the first task of the IPHE should be to conduct an overall review of what is ongoing worldwide to achieve a common view and identify meaningful IPHE activities.

This would provide the basis for a gap-analysis of the regulatory, codes, and standards requirements across all hydrogen production, delivery, storage, and use scenarios. 
The U.S. supports the IPHE Implementation and Liaison Committee focus on six recommended steps to sustainable hydrogen regulations, codes and standard:

- Establish a verifiable data base of technical information on hydrogen;

- Support development of performance-based regulations, codes and standards;

- Collect operational data on research, development and demonstration projects - supporting a common metric and reporting template for data collection;

- Support the adoption of harmonized international regulations, codes and standards;

- Establish appropriate Federal/state requirements for education and training in codes, standards and safety for officials, regulators, and the general public; and,

- Support public and technical forums to discuss events.

The IPHE could leverage the opportunities and success of one country as a pathway to introduction and validation in another. 
And the IPHE can encourage member governments to engage their regulatory bodies today in order to achieve domestic and international regulations before the target date of 2015.

We can learn from each small incident during the demonstration stages. We can improve our processes, protocols, and standards. We can, above all, share our experiences, our concerns, our insights, and our solutions.

Thank you. 